\title{
Cell culture models for studying the development of Barrett's esophagus: a systematic review
}

\author{
P. Bus • P. D. Siersema • J. W. P. M. van Baal
}

Accepted: 16 March 2012 / Published online: 3 April 2012

(C) The Author(s) 2012. This article is published with open access at Springerlink.com

\begin{abstract}
Background Barrett's esophagus (BE) is a premalignant condition caused by chronic gastroesophageal reflux. BE patients have an increased risk of developing esophageal adenocarcinoma (EAC). As many aspects of this condition are still unknown, there is a need for in vitro models to study BE development.

Aim To review the literature on cell lines and incubation conditions for studying BE development.

Methods A literature search was performed using PubMed, EMBASE and the Cochrane library, combining the words esophagus, cell line, culture, Barrett's, bile, acid, exposure, reflux and adenocarcinoma.

Results A wide range of cell lines and incubation conditions to study BE development have been reported. The most commonly used cell lines are derived from epithelium from patients with BE or EAC. A 25-minute incubation with $200 \mu \mathrm{M}$ bile salts induced cell proliferation and Akt phosphorylation. However, increased CDX2 and MUC2 expression was only observed with longer incubations or higher bile salt concentrations. Two-hundred $\mu \mathrm{M}$ bile at pH 6 showed a higher toxicity to EAC cells than the same concentration at $\mathrm{pH} 7$. Multiple 5-minute exposures with $200 \mu \mathrm{M}$ bile at $\mathrm{pH} 4$ or $\mathrm{pH} 7$ increased CK8/18 and COX2 in BE epithelial cells.

Conclusions Two-hundred $\mu \mathrm{M}$ conjugated primary or secondary bile salts at $\mathrm{pH} 4$ for multiple short exposures is able to induce $\mathrm{BE}$ specific factors in $\mathrm{BE}$ cell lines. In
\end{abstract}

P. Bus · P. D. Siersema · J. W. P. M. van Baal $(\square)$

Department of Gastroenterology and Hepatology,

University Medical Center Utrecht,

Heidelberglaan 100,

3584 CX Utrecht, The Netherlands

e-mail: J.W.P.M.vanbaal-2@umcutrecht.nl
SQ and EAC cell lines; however, higher concentrations of secondary bile salts for $8 \mathrm{~h}$ are needed to induce $\mathrm{BE}$ specific molecules. Due to the high variability in reported methods, it is difficult to determine the most effective in vitro setup for studying the development of $\mathrm{BE}$.

Keywords Bile salts · Acid · Reflux · Barrett's esophagus · In vitro model $\cdot$ Cell lines

$\begin{array}{ll}\text { Abbreviations } \\ \text { GERD } & \text { Gastro-esophageal reflux disease } \\ \text { BE } & \text { Barrett's esophagus } \\ \text { EAC } & \text { esophageal adenocarcinoma } \\ \text { CDX2 } & \text { caudal type homeobox transcription factor } 2 \\ \text { COX2 } & \text { cyclooxygenase-2 } \\ \text { MUC2 } & \text { mucin 2 } \\ \text { NF-kB } & \text { Nuclear Factor-kB } \\ \text { IL-8 } & \text { Interleukin-8 } \\ \text { MUC1 } & \text { mucin 1 } \\ \text { CK } & \text { cytokeratin } \\ \text { DCA } & \text { deoxycholic acid } \\ \text { ESCC } & \text { esophageal squamous cell cancer } \\ \text { LCA } & \text { lithocholic acid } \\ \text { GCDCA } & \text { glycochenodeoxycholic acid } \\ \text { CA } & \text { cholic acid } \\ \text { GCA } & \text { glycochenodeoxycholic acid } \\ \text { ROS } & \text { reactive oxygen species } \\ \text { CDCA } & \text { chenodeoxycholic acid } \\ \text { TCDCA } & \text { taurochenodeoxycholic acid } \\ \text { TCA } & \text { taurocholic acid } \\ \text { GDCA } & \text { glycodeoxycholic acid } \\ \text { TDCA } & \text { taurodeoxycholic acid } \\ \text { MCM4 } & \text { mini-chromosome maintenance protein } 4 \\ \text { EGR1 } & \text { early growth response gene 1 } \\ \text { VEGF } & \text { vascular endothelial cell growth factor } \\ & \end{array}$


GLCA glycolithocholic acid

TLCA taurolithocholic acid

UDCA ursodeoxycholic acid

GUDCA glycol-ursodeoxycholic acid

TUDCA tauro-ursodeoxycholic acid

NO nitric oxide

\section{Introduction}

Physiological reflux of gastric content from the stomach into the esophagus occurs in the majority of individuals [1]. When these reflux episodes occur more frequently, it will lead to gastroesophageal reflux disease (GERD). In patients with GERD, the refluxed fluid contains predominantly acid, which is exposed to the esophageal mucosa for a longer period of time compared to the physiologic situation [2]. GERD patients have also been shown to have higher concentrations of bile salts in the refluxate compared to healthy volunteers [3]. According to several studies, patients with GERD have an increased risk of developing Barrett's esophagus (BE) [4-6]. In BE, the normal squamous epithelium of the distal esophagus is replaced by intestinal metaplastic columnar-lined epithelium, containing goblet cells [7]. BE is a pre-malignant condition that predisposes to esophageal adenocarcinoma (EAC), with an incidence of approximately $0.5 \%$ per patient year [8-10]. This incidence is rising faster than that of any other malignancy in the Western world [11]. The prognosis of patients with EAC is mostly infaust with a 5-year survival rate of $10-15 \%$ [12].

It has been shown that the refluxate of BE patients also consists of higher concentrations of acid and bile salts compared to patients with GERD [3, 13]. Since long, it has been suggested that acid and bile salts play a predominant role in inducing $\mathrm{BE}$ and, when this condition is present, it may stimulate progression towards EAC. The exact mechanism remains however unknown.

Barrett's epithelium is characterized by the expression of several factors that distinguishes it from the normally present squamous epithelium in the distal esophagus, for example Caudal type Homeobox transcription factor 2 (CDX2), Cyclin D1, Cyclooxygenase-2 (COX2), Mucin 2 (MUC2) and Bone morphogenetic protein 4 (BMP4) [14-19]. Other factors that are expressed in BE include Nuclear Factor- $\kappa \mathrm{B}$ (NF-kB), Mucin 1 (MUC1), c-myc and the inflammatory cytokines Interleukin-8 (IL-8) and IL-1 $\beta$ [20-24]. Moreover, the phosphorylation of ERK $1 / 2$ is decreased, which is known to regulate proliferation and apoptosis [25]. Of special interest are the cytokeratins (CKs), which are often used to differentiate between normal squamous esophageal epithelium and BE [18]. CK10 and 13 are expressed in normal squamous esophageal epithelium, while CK7, 8, 18 and 20 expression is typically found in $\mathrm{BE}[16,18]$.
The metaplastic process causing esophageal squamous epithelial cells to transform into intestinal metaplastic columnar-lined epithelium (BE), followed by progression to EAC is complex [26]. In order to understand the pathogenetic mechanisms that induce $\mathrm{BE}$, it is important to know how bile salts and/or acid induce these changes and whether these processes can be inhibited. Since there is no good animal model available, an in vitro model, in which reflux of acid, bile or a combination, and its effects can be simulated and inhibited, would be useful. Over the last few years, several studies using various types of cell cultures to investigate the underlying mechanisms of bile and/or acid involved in BE development have been published. In this review, we will discuss these cell culture models with specific emphasis on cell lines, reflux components and incubation conditions.

\section{Methods}

A systematic search of the English-language literature indexed in PubMed, the Cochrane library and EMBASE was conducted that included a combination of the following search queries: esophagus, Barrett's, cell line, culture, bile, acid, exposure, reflux and adenocarcinoma. The search was performed for the period 1990 until October 2011. In addition, a manual search of citations in relevant articles was performed. In order to limit the focus of this review, papers using ex vivo cultures, colon cancer cell lines and esophageal squamous carcinoma cell lines, papers reporting patient studies, animal studies and previous reviews were excluded. Our query resulted in 159 papers. Fourty-six publications finally met the inclusion criteria.

\section{Results}

\subsection{Cell lines}

Cell lines have the advantage that large numbers can be grown and are expected to be a more or less stable model. In addition, cell lines can be cultured for a longer period than ex vivo cultures of esophageal squamous epithelial or Barrett's epithelial cells. In a study by Palanca-Wessels et al., the majority of primary (ex vivo) cultures of Barrett's epithelium were maintained for 1 week, whereas only a small number of cultures extended for longer periods, up to 4 months [27].

A disadvantage of cell lines is however that they can differentiate towards another cell type or that crosscontamination may occur, particularly when several cell lines are cultured simultaneously at the same site. Several studies using cells that had differentiated towards another cell type have been published [28, 29]. Another disadvantage is that 
cultured cell lines do not interact with other cell types or stroma, as these are not present in the culture, but likely play a role in overall functioning in the in vivo situation.

In the literature, various cell lines have been reported for studying the development of $\mathrm{BE}$, ranging from normal esophageal epithelial cell lines to BE and EAC cells. It is uncertain whether the cell lines that have been used in the literature indeed contain the specific cell characteristics as suggested. For example, Feagins et al. reported that their non-neoplastic Barrett's epithelial (BAR) cells behaved in fact as normal fibroblast cells and doubted their Barrett's origin [30]. Furthermore, Avissar et al. suggested that the EAC cell line Seg-1 had characteristics that are typical of lung epithelium [31]. Moreover, Alvarez et al. questioned the origin of several esophageal adenocarcinoma cell lines, among which were Seg-1 cells [32]. These cell lines have been widely used to study BE development [2, 17, 33-40].

From literature, it is known that the transformation of Barrett's metaplasia towards dysplastic epithelium and EAC is accompanied by an increase in genomic alterations and instability [41, 42]. This suggests that BE cell lines contain fewer genomic alterations; which can be of potential influence in an in vitro model, as the EAC cell lines will respond differently to bile and / or acid exposure than the BE cell lines. This might be an important factor to keep in mind, while setting up cell culture experiments. It is difficult to determine which cell line is the ideal in vitro model for induction of factors normally expressed in BE. This will often depend on the aim of the study and should be repeatedly determined for each experiment. Based on the in vitro results in the literature using the Seg-1 cell line incubated with bile salts at low or neutral $\mathrm{pH}$, this cell line could be an appropriate cell line to use; however, it has been suggested that these cells are not from an esophageal origin, but rather from lung epithelium [31]. Therefore, we suggest using a squamous esophageal epithelial (Het-1A), Barrett's epithelial (e.g. BAR-T) or EAC cell line (e.g. OE33) (Table 1).

Table 1 Cell lines for studying pathogenetic mechanisms of Barrett's esophagus

\begin{tabular}{ll}
\hline Cell lines & Cell type \\
\hline Het-1A & Squamous esophageal epithelial cell line \\
NES-B3T, & Cell line derived from squamous tissue from \\
NES-B10T & GERD patient with BE \\
NES-G2T, & Cell line derived from squamous tissue from \\
NES-G4T & GERD patient without BE \\
CP-D, BAR-T & Barrett's epithelial cells \\
OE33, OE19, & Esophageal adenocarcinoma cell line \\
FLO-1, SKGT4 & \\
\hline
\end{tabular}

Various cell lines used to study BE in an in vitro culture model along with the type of cell

\subsection{Bile salts at neutral $\mathrm{pH}$}

The type and concentration of bile salts in the gastroesophageal refluxate of $\mathrm{BE}$ patients has been determined in several studies $[13,43]$. Nehra et al. reported that the median bile salt concentration in BE patients was $181 \mu \mathrm{M}$ compared to $124 \mu \mathrm{M}$ in patients with erosive esophagitis and $14 \mu \mathrm{M}$ in patients with minimal mucosal injury [13]. The percentage of secondary bile salts was also higher in the refluxate of $\mathrm{BE}$ patients, compared to GERD patients and controls [13]. Secondary bile salts (e.g. deoxycholic acid (DCA), lithocholic acid (LCA) and their conjugated forms) are bile salts that are dehydroxylated and unionized at neutral $\mathrm{pH}$ and therefore more lipophilic, which may cause cell membrane rupture. Primary bile salts are cholic acid (CA) and chenodeoxycholic acid (CDCA) and these are the products of cholesterol metabolism. Takahashi et al. found that the bile hydrophobicity ratio is a predictor of developing $\mathrm{BE}$, in which the ratio is calculated by dividing the concentration of hydrophobic bile acids (LCA, glycolithocholic acid (GLCA) and taurolithocholic acid (TLCA)) through the concentration of hydrophilic bile acids (ursodeoxycholic acid (UDCA), glycol-ursodeoxycholic acid (GUDCA) and tauro-ursodeoxycholic acid (TUDCA)); LCA, GLCA and TLCA are in higher concentrations found in the $\mathrm{BE}$ reflux than in the reflux of non-BE patients [43]. Nehra et $a l$. also found that in BE patients, higher concentrations of conjugated bile acids are present [13]. Conjugation of bile acids leads to different toxic properties, with unconjugated bile acids and glycine conjugated bile salts having a higher toxicity than taurine conjugated bile acids. Bile acid toxicity has been investigated in Het-1A cells by Sharma et al. who found that CDCA, DCA and LCA dramatically decreased cell viability, while the conjugated forms of DCA and CDCA showed no change in viability [44]. Moreover, from LCA and DCA it is known that they play a role in colorectal carcinogenesis [45]. Based on these data, we can conclude that the most important bile acids in the development of $\mathrm{BE}$ are LCA, DCA, CDCA and glycine conjugated bile acids.

In several studies, reflux was simulated by exposing cell lines to different types of bile salts. The most frequently used bile salts are the secondary bile salt DCA $(1-1,000 \mu \mathrm{M})$ and the conjugated primary bile salt glycochenodeoxycholic acid (GCDCA) (50-1,000 $\mu \mathrm{M})$ [17, 36, 37, 46-48]. Bile salt mixtures have been used in concentrations ranging from $100-940 \mu \mathrm{M}$, and mostly consist of conjugated primary bile salts [34, 38, 48-51].

An increase in NF- $\mathrm{KB}$ activity was found in OE33 cells upon incubation with a secondary bile salt for $2 \mathrm{~h}$, while an even higher increase was measured after $8 \mathrm{~h}$ of incubation [47]. Incubation of BAR-T, Het-1A and OE33 cells with the same secondary bile salt resulted in increased production of reactive oxygen species (ROS) and nitric oxide (NO), DNA damage and NF- $\mathrm{kB}$ activity [52-54]. 
Increased IL-6 secretion was found upon incubation of OE33 cells with a primary bile salt [55]. Increased MUC2 and CDX2 expression was found upon exposure to 300 and $1,000 \mu \mathrm{M}$ DCA in Seg-1 cells [17], and lower concentrations of this bile salt $(50$ and $100 \mu \mathrm{M})$ were found to increase MUC2 and NF- $\mathrm{KB}$ expression [56]. An increase in MUC2 and CDX2 expression has been measured in Het-1A cells after exposure to $1,000 \mu \mathrm{M}$ DCA [17]. It has also been reported that lower concentrations (500 $\mathrm{MM}$ ) of (un-)conjugated primary bile salts were already sufficient to increase CDX2 expression in Het-1A cells [57]. CDX2 expression was also increased in OE19 cells (an EAC cell line) upon incubation with $100 \mu \mathrm{M}$ DCA; however, CDX2 protein levels were not changed [58].

Seg-1 cells showed a significant increase in proliferation rate, measured by cell count, upon incubation with a conjugated primary bile acid, with the highest increase in cell numbers at a concentration of $500 \mu \mathrm{M}$ [37]. Akt plays a role in the inhibition of apoptosis and the promotion of proliferation; its activity was found to be 3-fold increased in Seg-1 cells after exposure to the same conjugated primary bile acid, and after exposure to $300 \mu \mathrm{M}$ DCA [36, 59].

Keeping the normal clinical situation in mind, it seems most relevant to study the effect of bile salt mixtures in an in vitro model. We found 6 studies that used bile salt mixtures to simulate the gastroesophageal refluxate, an overview of these studies, together with the toxicity profile is shown in Table 2 [34, 38, 44, 48-51]. One bile mixture consisted for $80 \%$ of conjugated bile acids, incubation with this mixture did not show oxidative stress in EAC, BE and SQ cell lines [34]. The bile mixtures in the other 5 studies consisted of only conjugated bile acids. Incubation of Seg-1 cells with these mixtures caused an increase in CDX2 mRNA, but did not affect cell viability and oxidative stress [34, 38, 49]. Incubation of Het-1A cells with these mixtures decreased cell viability and increased CDX2 and MUC1 mRNA [48, 49, 51]. While FLO-1 cells (an EAC cell line) showed a decrease in cell viability upon incubation with these mixtures [48].

Exposure of Seg-1 cells, BAR cells and Het-1A cells to $200 \mu \mathrm{M}$ conjugated primary bile salts increased cell proliferation and Akt phosphorylation [36, 37]. NF- $\mathrm{BB}$ activation, MUC2 and CDX2 expression were however only induced after exposing cells to higher concentrations of secondary bile salts, i.e. 300 and 1,000 $\mu \mathrm{M}[17,47]$. Taken together, these results suggest that low concentrations of conjugated primary bile salts or higher concentrations of secondary bile salts can be used for incubation to see a BE specific effect. The bile mixtures that have been reported in the literature are mainly conjugated primary bile acids, with the results showing that these induce BE specific effects as well $[34,38,48,49,51]$.

\subsection{Acid}

A refluxate with a $\mathrm{pH}$ of 2 is rather common in $\mathrm{BE}$ patients [2]. However, the $\mathrm{pH}$ that is in contact with the esophageal epithelium is unlikely to be that low, as epithelial cells in vivo have a mucus layer at the apical side, which is able to neutralize at least partly the acid environment. When in vitro cell lines are used, this protection is not present, which makes it likely that a $\mathrm{pH}$ of 2 , when used in cell culture experiments, is more harmful than it actually is in vivo.

In the reported studies, cells were exposed to $\mathrm{pHs}$ ranging from $\mathrm{pH} 2$ to $\mathrm{pH} \mathrm{7,} \mathrm{with} \mathrm{proliferation} \mathrm{and} \mathrm{oxidative} \mathrm{stress}$ measured as endpoints [2, 30, 34, 38, 39, 47, 48, 60]. In Het$1 \mathrm{~A}$ and Seg-1 cells, exposure to $\mathrm{pH} 2$ or 4 for $1 \mathrm{~min}$ caused an increase in ROS formation, while another study showed that a 10-min exposure to $\mathrm{pH} 4$ did not result in increased oxidative stress [2, 34]. In addition, incubation of Seg-1 cells at pH 3.5 for $20 \mathrm{~min}$ did not result in increased cell proliferation or COX2 expression [38]. In contrast, Morgan et al. showed that the same incubation schedule caused suppression of the apoptosis-related protease, Caspase-9, and upregulation of Proliferating Cell Nuclear Antigen [39]. Moreover, a 10-minute exposure to $\mathrm{pH} 4$ caused ROS production and DNA damage in BAR-T cells [61]. Total cell numbers were found to be decreased, when BAR cells were incubated twice with medium acidified to $\mathrm{pH} 4$ for $3 \mathrm{~min}$, at intervals of 10, 60 or $120 \mathrm{~min}$ [30]. An increase in DNA damage was found in Het-1A cells after a 30minutes exposure to $\mathrm{pH} 4.5$ [48]. NF-KB activity was increased in OE33 cells upon incubation with $\mathrm{pH} 4$ for $1 \mathrm{~h}$ [47]. Moreover, a 1-hour exposure to $\mathrm{pH} 6$ caused an increase in Early Growth Response 1 gene (EGR1) expression in these cells. This gene encodes for a transcription factor which regulates cell proliferation and apoptosis [60].

According to the studies summarized above, both $\mathrm{pH} 2$ and $\mathrm{pH} 3.5$ damage cells and therefore should not be used in an in vitro model. In contrast, incubation conditions at $\mathrm{pH} 4$ and $\mathrm{pH} 6$ results in measurable effects. This was further illustrated by the finding that 1-hour exposure to $\mathrm{pH} 4$ in OE33 cells increased NF- $\mathrm{KB}$ activity, which has also been reported in ex vivo cultures of Barrett's tissue and EAC tissue, and in in vivo biopsies [47].

It can be concluded that incubating cell lines with $\mathrm{pH} 4$ seems to a large extent comparable to what is found in vivo; therefore this $\mathrm{pH}$ should be used in in vitro models when bile salts are not included in the incubation schedule.

\subsection{Bile salts at acidic $\mathrm{pH}$}

According to Nehra et al. reflux in BE patients mainly consists of bile salts at low or neutral $\mathrm{pH}$ [13]. Therefore, the combination of bile salts and acid is widely used in in vitro models. Bile salts can either be ionized or unionized 


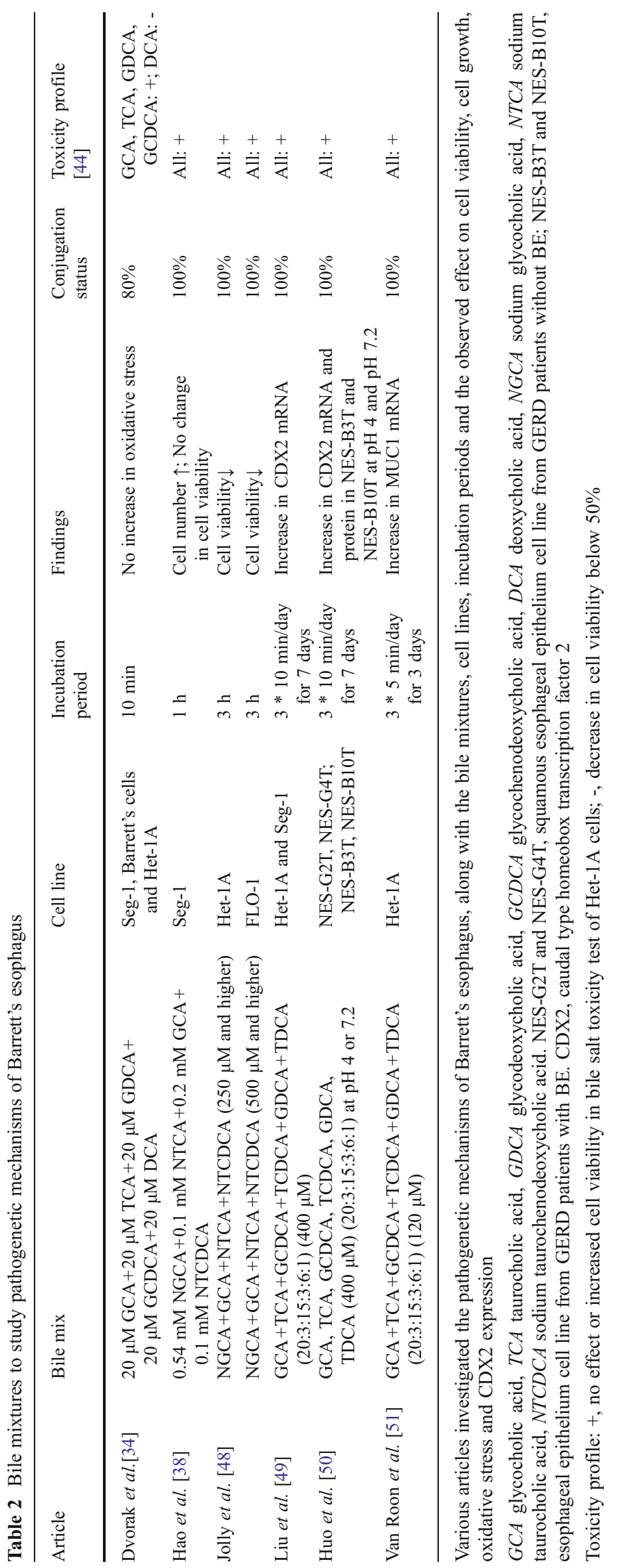


depending on the $\mathrm{pH}$ of the solution and the $\mathrm{pKa}$ value of the specific bile salt [62]. The pKa value of unconjugated bile salts is between 5.2-6.2, while glycine conjugates have a pKa of 3.8-4.8 and taurine conjugates a pKa of around 2 $[63,64]$. Lowering the $\mathrm{pH}$ towards these values may unionize bile salts, which makes them less soluble and able to enter the epithelial cells and influence intracellular pathways. Conjugation of bile acids results in a higher amount of bile salts in its soluble and ionized form at any given $\mathrm{pH}$, so a higher concentration of bile acids can reflux into the esophagus [65]. The $\mathrm{pH}$ range in which most bile acids exist in their soluble, unionized form is $\mathrm{pH} 3-6$. At these $\mathrm{pHs}$, bile acids can enter epithelial cells and affect important pathways [65]. At lower $\mathrm{pH}$, bile acids are precipitated and no longer damaging the epithelium, while at higher $\mathrm{pH}$, bile acids exist in their non-damaging ionized form [66]. This suggests that unconjugated and glycine conjugated bile acids are most toxic between $\mathrm{pH} 3-6$, while for taurine conjugated bile acids the $\mathrm{pH}$ needs to be approximately 2 to be able to pass the cell membrane.

Nine studies have reported on the combination of bile salts and acid to mimic reflux [34, 46, 48-50;67-69] (Table 3). Jolly et al. reported that a $\mathrm{pH} 4.5$ alone increased DNA damage in Het-1 A cells, which did not further increase upon exposure to $\mathrm{pH} 4.5$ in combination with a bile salt mixture [48]. Similar results were found by Jenkins et al., who found that incubation of OE33 cells with $200 \mu \mathrm{M}$ DCA at $\mathrm{pH} 5.5$ showed the same increase in DNA damage as DCA at $\mathrm{pH} 7$ [46]. These results suggest that low $\mathrm{pH}$ or bile salts alone are as toxic to these cells as bile salts at low $\mathrm{pH}$. However, incubation of the same cells with $100-400 \mu \mathrm{M}$ DCA at $\mathrm{pH}$ 6 enhanced toxicity to cells compared to DCA at pH 7 [46]. An increase in DNA damage was also reported in Het-1 A cells upon exposure to a $100 \mu \mathrm{M}$ bile mixture at $\mathrm{pH} 4$, with no difference if treated with acid alone [34]. In CP-A, CP-D (two Barrett's cell lines, metaplastic and dysplastic, respectively) and Seg-1 cells, DNA damage was however only seen after exposure to the combination of $100 \mu \mathrm{M}$ bile mixture at $\mathrm{pH} 4$ $[34,69]$. Feagins et al. showed that ROS production is increased in BAR-T, NES-B3T and in NES-G2T cell lines (the latter two are cell lines derived from squamous tissue from GERD patients with or without BE, respectively) upon incubation with a conjugated bile salt at $\mathrm{pH} 4$; these cell lines used however different mechanisms to increase this production [67]. These data suggest that already significant changes occur in the transition of reflux esophagitis towards BE.

The most frequently reported bile salt concentrations in vitro are $100 \mu \mathrm{M}$ and $200 \mu \mathrm{M}$ conjugated primary and secondary bile salts, and 100 and $200 \mu \mathrm{M}$ bile mixture at $\mathrm{pH} 4-6$, consisting for $80 \%$ out of conjugated bile salts and for $60 \%$ out of primary bile salts. An increased toxicity has been found in OE33 cells upon a 1-hour incubation with 100 or $200 \mu \mathrm{M}$ secondary bile salt at pH 5.5 and in Het-1A cells upon incubation with a $100 \mu \mathrm{M}$ bile mixture at $\mathrm{pH} 4.5$ for $15 \min [46,48]$.

It can be concluded from these results that the combination of 100 or $200 \mu \mathrm{M}$ bile salts, either conjugated primary or unconjugated secondary bile salts, at $\mathrm{pH} 4$ seems the most optimal and physiological culture condition for cell lines, as demonstrated by the observations that these conditions show a higher toxicity compared to bile salts at $\mathrm{pH} 7[34,46,48]$.

\subsection{Incubation periods}

It is not sure whether BE develops after prolonged and/or chronic exposure of esophageal squamous epithelial cells to a refluxate containing bile salts and acid, or, alternatively, whether just one period of severe reflux causing severe damage to the esophageal lining is causing this premalignant condition [70]. Based on 24-hour $\mathrm{pH}$ monitoring, the incubation period that is most comparable to the reflux episodes in vivo is approximately $3 \mathrm{~min}$ [71]. However, in order to obtain comparable results as in the in vivo situation, incubation periods should probably be longer; Since, even negative controls experience reflux episodes, measured by $\mathrm{pH}$ monitoring $[13,72]$.

In the literature, various different incubation periods have been reported, ranging from $1 \mathrm{~min}$ to up to $48 \mathrm{~h}[2,17,24$, $34,36-39,46-48,55,57,60,67,73-77]$. The shorter incubation periods, ranging from 1-20 min, are summarized in Table 4. A 3-minute exposure to $200 \mu \mathrm{M}$ conjugated primary bile salt caused an increase in oxidative stress in BAR-T, NES-G2T and NES-B3T cells, while an exposure of $10 \mathrm{~min}$ to a $100 \mu \mathrm{M}$ bile mixture at $\mathrm{pH} 4$ caused oxidative stress in Seg-1 cells [34, 67]. Exposure of OE33 cells to a secondary bile salt at $\mathrm{pH} 5$ caused an increase in CDX2 expression [75]. An exposure of $15 \mathrm{~min}$ to $\mathrm{pH} 4.5$ alone caused a higher increase in DNA damage in FLO-1 cells and Het-1A cells than exposure to a $100 \mu \mathrm{M}$ bile mixture at $\mathrm{pH}$ 4.5 using the same incubation time [48].

The results from longer incubation periods, from $1-48 \mathrm{~h}$, are shown in Table 5.

Exposure times of 1 and $24 \mathrm{~h}$ have most frequently been used. The effects that are measured upon a 1-hour exposure to bile salts or acid are consistent with those occurring in vivo, such as an increase in NF-KB activity [47], cell proliferation [38] and EGR1 expression [60].

Reflux episodes occur more frequently in patients with GERD and BE compared to healthy controls [78], this suggests that multiple or pulsatile exposures of cell cultures to acid and/or bile salt seem to correspond most optimal to the clinical situation. This approach was used in five studies $[30,49,51,79,80]$. In one study, BAR-T cells were incubated with conjugated primary bile salts at $\mathrm{pH} 4, \mathrm{pH} 6$ and $\mathrm{pH} 7.4$ for $5 \mathrm{~min}$ [79]. A single exposure did not result in a measurable effect, while daily exposures of $5 \mathrm{~min}$ for a 


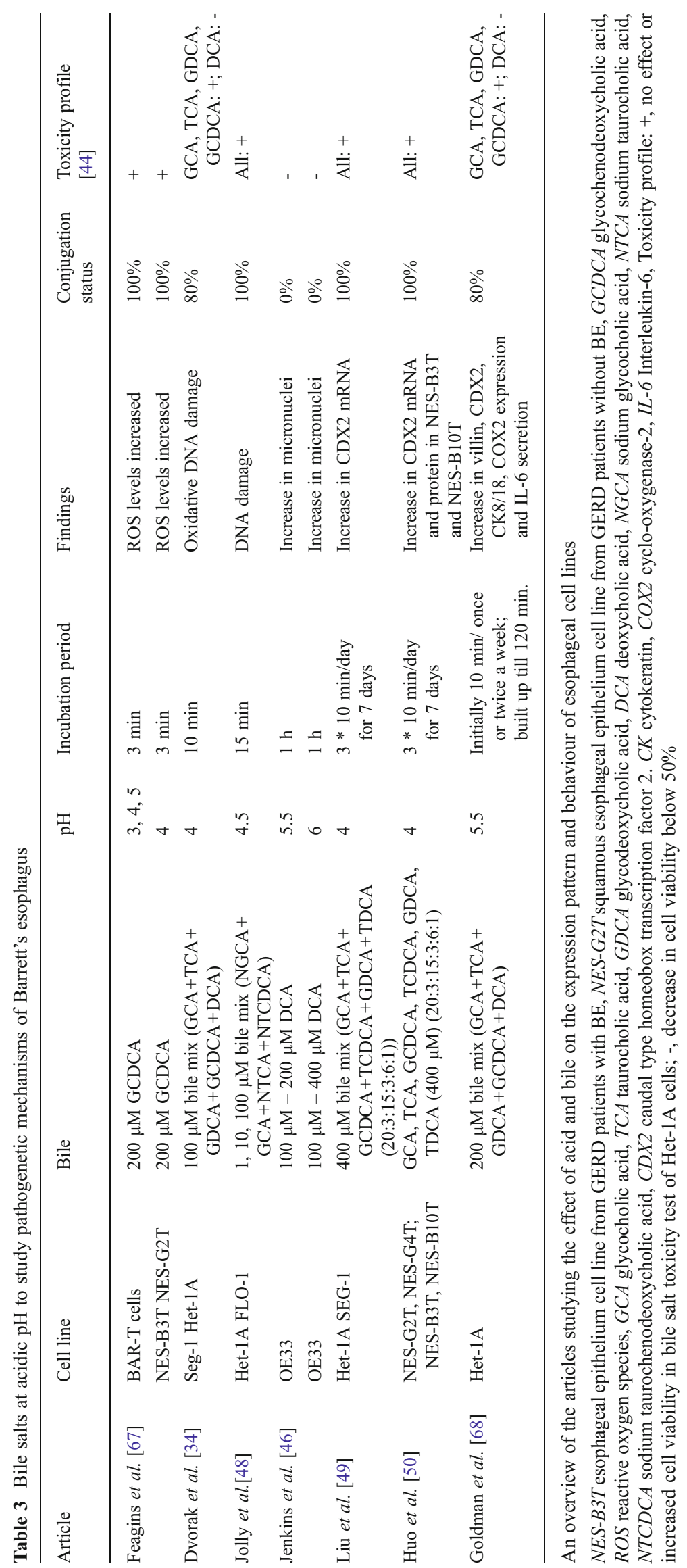


Table 4 The effect of the different durations of bile salt and/or acid incubations on the behaviour of the cell lines

\begin{tabular}{|c|c|c|c|}
\hline Time (min) & $\begin{array}{l}\text { Squamous esophageal } \\
\text { epithelial cells (Het-1A) }\end{array}$ & Barrett's epithelial cells (BAR-T) & $\begin{array}{l}\text { Adenocarcinoma cells } \\
\text { (Seg-1, FLO-1, OE33, OE21) }\end{array}$ \\
\hline 1 & $\begin{array}{l}\text { pH } 2, \mathrm{pH} 4 \rightarrow \text { oxidative } \\
\text { stress [2] }\end{array}$ & & pH $2 \rightarrow$ oxidative stress [2] \\
\hline 3 & & $\begin{array}{l}200 \mu \mathrm{M} \text { GCA at } \mathrm{pH} 4 \rightarrow \text { oxidative } \\
\text { stress [67] }\end{array}$ & \\
\hline 5 & & $50 \mu \mathrm{M} \mathrm{CDCA} \rightarrow$ cell proliferation $\uparrow[37]$ & $\begin{array}{l}50-100 \mu \mathrm{M} \text { TCA at } \mathrm{pH} 3-4.5 \rightarrow \text { ERK and } \mathrm{p} 38 \\
\text { activation [74] }\end{array}$ \\
\hline \multirow[t]{2}{*}{10} & & & $100 \mu \mathrm{M}$ bile mix at $\mathrm{pH} 4 \rightarrow$ oxidative stress [34] \\
\hline & & & $100 \mu \mathrm{M}$ DCA at $\mathrm{pH} 5 \rightarrow \mathrm{CDX} 2, \mathrm{VEGF} \uparrow[75]$ \\
\hline \multirow[t]{2}{*}{15} & $100 \mu \mathrm{M}$ bile mix at $\mathrm{pH} 4.5 \rightarrow$ & & $100 \mu \mathrm{M}$ bile mix at $\mathrm{pH} 4.5 \rightarrow$ DNA damage [48] \\
\hline & DNA damage [48] & & pH $3.5 \rightarrow$ no change in cell proliferation $[38]$ \\
\hline \multirow[t]{2}{*}{20} & & & pH $3.5 \rightarrow$ no change in cell proliferation $[38]$ \\
\hline & & & 50-1000 $\mu \mathrm{M}$ GCDCA $\rightarrow$ cell proliferation $\uparrow[36]$ \\
\hline
\end{tabular}

An overview of the changes measured upon one short exposure to bile salts and/or acid

$G C A$ glycocholic acid, $C D C A$ chenodeoxycholic acid, $T C A$ taurocholic acid, $D C A$ deoxycholic acid, $C D X 2$ caudal type homeobox transcription factor 2, VEGF vascular endothelial growth factor, $G C D C A$ glycochenodeoxycholic acid

period of 2-6 weeks made these cells showing a more colonic phenotype, characterized by expression of CK8/18, as well as a colonic epithelial protein, which is specifically expressed in colonic epithelial and BE cells [79]. Another study showed that daily 5-minute exposures of BAR-T cells to a conjugated primary bile salt for 22 weeks, increased the COX2 expression 10-fold [80]. The other studies showed that exposure of BAR cells to two 3-minute incubations of $\mathrm{pH} 4$ at 10-, 60- or 120minute intervals decreased cell numbers; that three 10 -minute exposures per day to $400 \mu \mathrm{M}$ bile mixture at acidic and neutral

Table 5 The effect of the different durations of bile salt and/or acid incubations on the behaviour of the cell lines

\begin{tabular}{|c|c|c|}
\hline Time (hrs) & Squamous esophageal epithelial cells (Het-1A) & Adenocarcinoma cells (Seg-1, FLO-1, OE33, SKGT4) \\
\hline \multirow[t]{4}{*}{1} & & $940 \mu \mathrm{M}$ bile mix $\rightarrow$ cell proliferation $\uparrow[38]$ \\
\hline & & 100 or $200 \mu \mathrm{M}$ DCA $\rightarrow$ DNA damage $\uparrow[46]$ \\
\hline & & pH $4 \rightarrow$ NF- $\kappa$ B activity $\uparrow[47]$ \\
\hline & & pH 6-7 $\rightarrow$ EGR1 mRNA $\uparrow[60]$ \\
\hline 2 & & $300 \mu \mathrm{M} \mathrm{DCA} \rightarrow \mathrm{NF}-\kappa \mathrm{B}$ activity $\uparrow[47]$ \\
\hline 3 & $250 \mu \mathrm{M}$ bile mix $\rightarrow$ cell viability $\downarrow[48]$ & $500 \mu \mathrm{M}$ bile mix $\rightarrow$ cell viability $\downarrow[48]$ \\
\hline \multirow[t]{3}{*}{4} & & $1000 \mu \mathrm{M}$ DCA $\rightarrow \mathrm{CDX} 2, \mathrm{MUC} 2 \uparrow[17]$ \\
\hline & & $300 \mu \mathrm{M} \mathrm{DCA} \rightarrow \mathrm{COX} 2 \uparrow[73]$ \\
\hline & & $300 \mu \mathrm{M}$ DCA $\rightarrow$ IL-8, IкB $\uparrow[77]$ \\
\hline 8 & $1000 \mu \mathrm{M} \mathrm{DCA} \rightarrow \mathrm{MUC} 2, \mathrm{CDX} 2 \uparrow[17]$ & $300 \mu \mathrm{M}$ DCA $\rightarrow$ MUC2, CDX2 $\uparrow[17]$ \\
\hline 18 & & 50,100 or $300 \mu \mathrm{M}$ DCA, CDCA or TCA $\rightarrow$ NF- $\kappa \mathrm{B}$ and MUC2 $\uparrow[56]$ \\
\hline \multirow[t]{5}{*}{24} & $\begin{array}{l}200,500 \mu \mathrm{M} \mathrm{CA}, 500 \mu \mathrm{M} \text { GCA or } 1000 \mu \mathrm{M} \\
\mathrm{DCA} \rightarrow \mathrm{CDX} 2 \uparrow[57]\end{array}$ & $1000 \mu \mathrm{M} \mathrm{DCA} \rightarrow \mathrm{CDX} 2, \mathrm{MUC} 2 \uparrow[17]$ \\
\hline & & $50,100,200 \mu \mathrm{M}$ DCA $\rightarrow$ oxidative stress and micronuclei $\uparrow[46]$ \\
\hline & & $\begin{array}{l}500 \mu \mathrm{M} \text { TCA, } 1000 \mu \mathrm{M} \text { TDCA, } 500 \mu \mathrm{M} \text { TCDCA, } 500 \mu \mathrm{M} \text { GCA } \\
\quad \text { or } 50 \mu \mathrm{M} \text { DCA } \rightarrow \text { MUC } 1 \uparrow[76]\end{array}$ \\
\hline & & $100 \mu \mathrm{M}$ DCA or CDCA with/without $\mathrm{pH} 4 \rightarrow \mathrm{c}-\mathrm{myc} \uparrow[24]$ \\
\hline & & $100 \mu \mathrm{M}$ DCA $\rightarrow \mathrm{CDX} 2, \mathrm{VEGF} \uparrow[75]$ \\
\hline 48 & & $100 \mu \mathrm{M}$ CDCA $\rightarrow$ IL-6 secretion $\uparrow[55]$ \\
\hline
\end{tabular}

An overview of the changes measured upon one longer exposure to bile salts and/or acid

$D C A$ deoxycholic acid, $N F-\kappa B$ Nuclear Factor- $\mathrm{\kappa B}, E G R 1$ early growth response gene 1, $C D X 2$ caudal type homeobox transcription factor 2 , $M U C 2$ mucin 2, GCA glycocholic acid, $C A$ cholic acid. COX2 cyclooxygensase-2, IL-8 Interleukin-8, CDCA chenodeoxycholic acid, $T C A$ taurocholic acid, TDCA taurodeoxycholic acid, TCDCA taurochenodeoxycholic acid, GCA glycocholic acid, MUC1 mucin 1, VEGF vascular endothelial growth factor 
$\mathrm{pH}$ resulted in an increase in CDX2 expression in Het-1A and SEG-1 cells and that 5-minute exposures 3 times per day for 3 days to $120 \mu \mathrm{M}$ bile mixture caused an increase in MUC1 expression in Het-1A cells [30, 49, 51].

In summary, repeated 3- or 5-minutes exposures or one single exposure of $1 \mathrm{~h}$ to bile salts and / or low $\mathrm{pH}$ result in BE specific changes in vitro.

\section{Summary}

In Table 6, an overview of the in vitro changes in the several cell lines upon incubation with bile salts at low or neutral $\mathrm{pH}$ are shown, together with the changes known to occur in BE patients. In SQ cell lines, CDX2 and MUC2 mRNA is increased upon incubation with a secondary bile salt [17]. In Barrett's cell lines either one exposure or multiple exposures to a conjugated primary bile salt, results in an upregulation of $\mathrm{BE}$ specific factors, e.g. $\operatorname{COX} 2[37,79]$. In an EAC cell line, one incubation with a secondary bile salt results in the upregulation of CDX2, MUC2 and NF- $\mathrm{KB}[17,47]$. In an in vivo model of BE in rats, in which $\mathrm{BE}$ is induced by performing an esophagogastroduodenal anastomosis, it has been shown that COX2, CDX2 and MUC2 is upregulated [81, 82]. Moreover, in BE biopsies it has been shown that CDX2, CK $7 / 8 / 18 / 20$, COX2 and MUC2 expression is increased, along with an increased $\mathrm{NF}-\mathrm{KB}$ activation and an increased proliferation [15-18]. These changes also occur in the in vitro models mentioned in Table 6. Taken together, the in vitro models shown in Table 6 are the most ideal models that can be used to study the development of BE.

\section{Discussion}

The last decades, both $\mathrm{BE}$ and EAC have dramatically risen in incidence [83]. Patients with $\mathrm{BE}$ have an increased risk of developing EAC, with an annual incidence of approximately $0.5 \%$ [8-11]. For this reason, endoscopic surveillance programs for BE patients have been developed to detect early stage EAC aiming to improve the prognosis of $\mathrm{BE}$ patients diagnosed with EAC [84].

It is currently largely unknown by which mechanism(s) BE develops. It has been suggested that at least partly a genetic basis is involved [85, 86]; however, the type and severity of gastroesophageal reflux is most probably involved as well $[3,13]$. Unfortunately, an animal model that is clearly representing the situation in humans is not available. The most used animal models are variants of surgical rat models, which are physiologically not similar to humans and require long time periods to develop $\mathrm{BE}$ and $\mathrm{EAC}$ [87, 88]. Rodents also have keratinized epithelium and no submucosal glands, which is the opposite to the human epithelium [89]. In addition, there is a high mortality rate after the surgical procedure, a low incidence of $\mathrm{BE}$ lesions, uncertainty about the true nature of the lesion and the progression to malignancy is not similar to human malignant progression [90-92]. Finally, knocking out certain genes in rats is rather complicated, if not impossible.

Therefore, until there are animal models available that are validated for studying $\mathrm{BE}$ and $\mathrm{EAC}$, we need to rely on ex vivo and in vitro models. The latter are easiest to use, as in vitro models have the advantage that they are widely available, can be cultured for longer periods and are not dependent on the presence of patients with BE. It is important

Table 6 In vivo and in vitro reflux episodes and their induced changes

\begin{tabular}{|c|c|c|c|c|c|}
\hline & $\begin{array}{l}\text { Barrett's epithelium } \\
\text { of BE patients }\end{array}$ & $\begin{array}{l}\text { Squamous esophageal } \\
\text { epithelial cell lines }\end{array}$ & Barrett's cell lines & & $\begin{array}{l}\text { Esophageal } \\
\text { adenocarcinoma } \\
\text { cell lines }\end{array}$ \\
\hline Exposure: & $181 \mu \mathrm{M}$ bile $\operatorname{mix}[13]$ & $1000 \mu \mathrm{M}$ DCA & $200 \mu \mathrm{M}$ GCDCA & $\begin{array}{c}200 \mu \mathrm{M} \text { GCDCA } \\
\text { at } \mathrm{pH} 4 \text { or } 7.4\end{array}$ & $300 \mu \mathrm{M}$ DCA \\
\hline Incubation period: & $\begin{array}{l}\text { Multiple reflux episodes } \\
\text { with an average duration } \\
\text { of } 2.6 \mathrm{~min}[71]\end{array}$ & $8 \mathrm{~h}$ & $5 \mathrm{~min}$ & $\begin{array}{l}\text { Multiple incubations } \\
\text { of } 5 \mathrm{~min}\end{array}$ & $8 \mathrm{~h}$ \\
\hline \multirow[t]{6}{*}{ Upregulation of: } & $\mathrm{CDX} 2$ & CDX2 [17] & \multirow[t]{6}{*}{ Cell proliferation $\uparrow[37]$} & CK8, 18 [79] & CDX2 [17] \\
\hline & CK $7,20,8,18$ & MUC2 [17] & & COX2 [79] & MUC2 [17] \\
\hline & $\mathrm{COX} 2$ & & & & NF-кB [47] \\
\hline & MUC2 & & & & \\
\hline & $\mathrm{NF}-\kappa \mathrm{B}$ & & & & \\
\hline & Cell proliferation $\uparrow$ & & & & \\
\hline
\end{tabular}

The effect of bile and different incubation periods on the expression pattern and behaviour of esophageal cell lines and the changes on the expression in vivo

$D C A$ deoxycholic acid, GCDCA glycochenodeoxycholic acid, $C D X 2$ caudal type homeobox transcription factor 2, $C K$ cytokeratin, $C O X 2$ cyclooxygenase 2, MUC2 mucin 2, NF- $\kappa B$ Nuclear Factor- $\mathrm{kB}$ 
that there is consensus on which in vitro model to use, in order to combine the results of different studies.

In this review, we reported a large variety of in vitro models that have been reported to induce factors normally expressed in BE. This review shows that many different cell lines and incubation conditions are available, and, in addition, the measured outcome parameters are often different. It is therefore difficult to conclude that there is a single most perfect in vitro model to study BE development.

It seems likely that the choice for a specific cell line to investigate pathogenetic mechanisms in $\mathrm{BE}$ largely depends on the research question. If the aim is to study the process of metaplasia of normal esophageal squamous epithelial cell to a Barrett's like cell type, esophageal squamous epithelium cell lines, such as Het-1A cells, are most appropriate to use in an in vitro model. For other research questions, particularly the development of esophageal adenocarcinoma, BAR-T or OE33 cells can be used. It is, however, important to keep in mind that cell lines are usually transformed in order to keep the cells continuously growing, and therefore may behave differently compared to esophageal cells growing in vivo. Moreover, the microenvironment is also not present in an in vitro system, i.e., cells do not interact with other cell types, particularly inflammatory cells, or with products secreted by the surrounding stroma, i.e., growth factors and inflammatory mediators, which also play a role in the grow pattern and functioning of esophageal lining cells.

From the reviewed studies it can be concluded that in vitro bile salts at either a low or neutral $\mathrm{pH}$ are required to induce the changes that are seen in $\mathrm{BE}$, such as NF- $\mathrm{KB}$ activation and increased cell proliferation. Based on our review, we suggest that a combination of bile salts and acid, i.e., 100 or $200 \mu \mathrm{M}$ conjugated primary bile salts at $\mathrm{pH} 4$ for $1 \mathrm{~h}$, seems the most optimal culture condition to induce a Barrett's like phenotype. This concentration of bile salts at low $\mathrm{pH}$ is similar to what is found in the refluxate of BE patients and has been shown to induce DNA damage $[13,34]$. In addition, incubation with $\mathrm{pH} 4$ alone increased NF-kB activity and incubation with 100 or $200 \mu \mathrm{M}$ bile salt at neutral $\mathrm{pH}$ increased MUC2 and CDX2 expression [47, 56, 58]. An alternative experimental in vitro model includes multiple short exposures to bile salts and/or acid, which is comparable to the gastroesophageal reflux episodes that occur in GERD [49, 50, 79]. Moreover, multiple incubations with $200 \mu \mathrm{M}$ bile salt at $\mathrm{pH} 4$ induced the upregulation of CK8, CK18 and COX2 [79].

In conclusion, this data suggests that some selected in vitro cell line systems are able to induce the expression of markers that are specific for Barrett's epithelium. When these models are used it may well be that our knowledge on the pathogenesis of the development of $\mathrm{BE}$ and its progression towards EAC can be improved.
Open Access This article is distributed under the terms of the Creative Commons Attribution License which permits any use, distribution, and reproduction in any medium, provided the original author(s) and the source are credited.

\section{References}

1. J.P. Galmiche, R.E. Clouse, A. Balint, I.J. Cook, P.J. Kahrilas, W.G. Paterson, A.J. Smout, Functional esophageal disorders. Gastroenterology 130, 1459-1465 (2006)

2. K. Dvorak, R. Fass, R. Dekel, C.M. Payne, M. Chavarria, B. Dvorakova, H. Bernstein, C. Bernstein, H. Garewal, Esophageal acid exposure at $\mathrm{pH}<\mathrm{or}=2$ is more common in Barrett's esophagus patients and is associated with oxidative stress. Dis Esophagus 19, 366-372 (2006)

3. W.K. Kauer, J.H. Peters, T.R. DeMeester, H. Feussner, A.P. Ireland, H.J. Stein, R.J. Siewert, Composition and concentration of bile acid reflux into the esophagus of patients with gastroesophageal reflux disease. Surgery 122, 874-881 (1997)

4. G.M. Eisen, R.S. Sandler, S. Murray, M. Gottfried, The relationship between gastroesophageal reflux disease and its complications with Barrett's esophagus. Am J Gastroenterol. 92, 27-31 (1997)

5. M.A. Eloubeidi, D. Provenzale, Clinical and demographic predictors of Barrett's esophagus among patients with gastroesophageal reflux disease: a multivariable analysis in veterans. J Clin Gastroenterol. 33, 306-309 (2001)

6. J. Ronkainen, P. Aro, T. Storskrubb, S.E. Johansson, T. Lind, E. Bolling-Sternevald, M. Vieth, M. Stolte, N.J. Talley, L. Agreus, Prevalence of Barrett's esophagus in the general population: an endoscopic study. Gastroenterology 129, 1825-1831 (2005)

7. R.J. Playford, New British Society of Gastroenterology (BSG) guidelines for the diagnosis and management of Barrett's oesophagus. Gut 55, 442 (2006)

8. J. Lagergren, R. Bergstrom, A. Lindgren, O. Nyren, Symptomatic gastroesophageal reflux as a risk factor for esophageal adenocarcinoma. N Engl J Med. 340, 825-831 (1999)

9. N.J. Shaheen, M.A. Crosby, E.M. Bozymski, R.S. Sandler, Is there publication bias in the reporting of cancer risk in Barrett's esophagus? Gastroenterology 119, 333-338 (2000)

10. M. Hage, P.D. Siersema, H. van Dekken, E.W. Steyerberg, J. Dees, E.J. Kuipers, Oesophageal cancer incidence and mortality in patients with long-segment Barrett's oesophagus after a mean follow-up of 12.7 years. Scand J Gastroenterol. 39, 1175-1179 (2004)

11. H. Pohl, H.G. Welch, The role of overdiagnosis and reclassification in the marked increase of esophageal adenocarcinoma incidence. J Natl Cancer Inst. 97, 142-146 (2005)

12. M.A. Eloubeidi, A.C. Mason, R.A. Desmond, H.B. el-Serag, Temporal trends (1973-1997) in survival of patients with esophageal adenocarcinoma in the United States: a glimmer of hope? Am J Gastroenterol. 98, 1627-1633 (2003)

13. D. Nehra, P. Howell, C.P. Williams, J.K. Pye, J. Beynon, Toxic bile acids in gastro-oesophageal reflux disease: influence of gastric acidity. Gut 44, 598-602 (1999)

14. F. Milano, J.W. van Baal, N.S. Buttar, A.M. Rygiel, F. de Kort, C.J. DeMars, W.D. Rosmolen, J.J. Bergman, J. Van Marle, K.K. Wang, M.P. Peppelenbosch, K.K. Krishnadath, Bone morphogenetic protein 4 expressed in esophagitis induces a columnar phenotype in esophageal squamous cells. Gastroenterology 132, 2412-2421 (2007)

15. T.J. Jang, M.Y. Cho, Cyclooxygenase-2 expression and cell proliferation are increased in MUC2-positive area of columnarlined esophagus. Pathol Int. 55, 546-549 (2005) 
16. J.W. van Baal, F. Milano, A.M. Rygiel, J.J. Bergman, W.D. Rosmolen, S.J. van Deventer, K.K. Wang, M.P. Peppelenbosch, K.K. Krishnadath, A comparative analysis by SAGE of gene expression profiles of Barrett's esophagus, normal squamous esophagus, and gastric cardia. Gastroenterology 129, 1274-1281 (2005)

17. Y. Hu, C. Jones, O. Gellersen, V.A. Williams, T.J. Watson, J.H. Peters, Pathogenesis of Barrett esophagus: deoxycholic acid upregulates goblet-specific gene MUC2 in concert with CDX2 in human esophageal cells. Arch Surg. 142, 540-544 (2007)

18. J.W. van Baal, A. Bozikas, R. Pronk, F.J. Ten Kate, F. Milano, A.M. Rygiel, W.D. Rosmolen, M.P. Peppelenbosch, J.J. Bergman, K.K. Krishnadath, Cytokeratin and CDX-2 expression in Barrett's esophagus. Scand J Gastroenterol. 43, 132-140 (2008)

19. K. Bani-Hani, I.G. Martin, L.J. Hardie, N. Mapstone, J.A. Briggs, D. Forman, C.P. Wild, Prospective study of cyclin D1 overexpression in Barrett's esophagus: association with increased risk of adenocarcinoma. J Natl Cancer Inst. 92, 1316-1321 (2000)

20. J.M. O'Riordan, M.M. Abdel-Latif, N. Ravi, D. McNamara, P.J. Byrne, G.S. McDonald, P.W. Keeling, D. Kelleher, J.V. Reynolds, Proinflammatory cytokine and nuclear factor kappa-B expression along the inflammation-metaplasia-dysplasia-adenocarcinoma sequence in the esophagus. Am J Gastroenterol. 100, 12571264 (2005)

21. I. Hritz, H. Gyorffy, B. Molnar, G. Lakatos, F. Sipos, I. Pregun, M. Juhasz, L. Pronai, Z. Schaff, Z. Tulassay, L. Herszenyi, Increased p53 expression in the malignant transformation of Barrett's esophagus is accompanied by an upward shift of the proliferative compartment. Pathol Oncol Res. 15, 183-192 (2008)

22. K.K. Krishnadath, H.W. Tilanus, M. van Blankenstein, F.T. Bosman, A.H. Mulder, Accumulation of p53 protein in normal, dysplastic, and neoplastic Barrett's oesophagus. J Pathol. 175, 175-180 (1995)

23. J.N. Glickman, P.L. Blount, C.A. Sanchez, D.S. Cowan, V.J. Wongsurawat, B.J. Reid, R.D. Odze, Mucin core polypeptide expression in the progression of neoplasia in Barrett's esophagus. Hum Pathol. 37, 1304-1315 (2006)

24. C. Tselepis, C.D. Morris, D. Wakelin, R. Hardy, I. Perry, Q.T. Luong, E. Harper, R. Harrison, S.E. Attwood, J.A. Jankowski, Upregulation of the oncogene c-myc in Barrett's adenocarcinoma: induction of c-myc by acidified bile acid in vitro. Gut 52, 174-180 (2003)

25. J.W. van Baal, S.H. Diks, R.J. Wanders, A.M. Rygiel, F. Milano, J. Joore, J.J. Bergman, M.P. Peppelenbosch, K.K. Krishnadath, Comparison of kinome profiles of Barrett's esophagus with normal squamous esophagus and normal gastric cardia. Cancer Res. 66, 11605-11612 (2006)

26. C.P. Morales, R.F. Souza, S.J. Spechler, Hallmarks of cancer progression in Barrett's oesophagus. Lancet 360, 1587-1589 (2002)

27. M.C. Palanca-Wessels, M.T. Barrett, P.C. Galipeau, K.L. Rohrer, B.J. Reid, P.S. Rabinovitch, Genetic analysis of long-term Barrett's esophagus epithelial cultures exhibiting cytogenetic and ploidy abnormalities. Gastroenterology 114, 295-304 (1998)

28. G.N. Stacey, Cell contamination leads to inaccurate data: we must take action now. Nature 403, 356 (2000)

29. J.J. Boonstra, A.W. van der Velden, E.C. Beerens, R. van Marion, Y. Morita-Fujimura, Y. Matsui, T. Nishihira, C. Tselepis, P. Hainaut, A.W. Lowe, B.H. Beverloo, H. van Dekken, H.W. Tilanus, W.N. Dinjens, Mistaken identity of widely used esophageal adenocarcinoma cell line TE-7. Cancer Res. 67, 7996-8001 (2007)

30. L.A. Feagins, H.Y. Zhang, K. Hormi-Carver, M.H. Quinones, D. Thomas, X. Zhang, L.S. Terada, S.J. Spechler, R.D. Ramirez, R.F. Souza, Acid has antiproliferative effects in nonneoplastic Barrett's epithelial cells. Am J Gastroenterol. 102, 10-20 (2007)
31. N.E. Avissar, L. Toia, Y. Hu, T.J. Watson, C. Jones, D.P. Raymond, A. Matousek, J.H. Peters, Bile acid alone, or in combination with acid, induces CDX2 expression through activation of the Epidermal Growth Factor Receptor (EGFR). J Gastrointest Surg. 13, 212-222 (2008)

32. H. Alvarez, J.B. Koorstra, S.M. Hong, J.J. Boonstra, W.N. Dinjens, T.T. Wu, E. Montgomery, J.R. Eshleman, A. Maitra, Establishment and characterization of a bona fide barrett esophagus-associated adenocarcinoma cell line. Cancer Biol Ther. 7, 1753-1755 (2008)

33. K. Dvorak, M. Chavarria, C.M. Payne, L. Ramsey, C. CrowleyWeber, B. Dvorakova, B. Dvorak, H. Bernstein, H. Holubec, R.E. Sampliner, C. Bernstein, A. Prasad, S.B. Green, H. Garewal, Activation of the interleukin-6/STAT3 antiapoptotic pathway in esophageal cells by bile acids and low $\mathrm{pH}$ : relevance to barrett's esophagus. Clin Cancer Res. 13, 5305-5313 (2007)

34. K. Dvorak, C.M. Payne, M. Chavarria, L. Ramsey, B. Dvorakova, H. Bernstein, H. Holubec, R.E. Sampliner, N. Guy, A. Condon, C. Bernstein, S.B. Green, A. Prasad, H.S. Garewal, Bile acids in combination with low $\mathrm{pH}$ induce oxidative stress and oxidative DNA damage: relevance to the pathogenesis of Barrett's oesophagus. Gut 56, 763-771 (2007)

35. G.A. Sarosi Jr., K. Jaiswal, E. Herndon, C. Lopez-Guzman, S.J. Spechler, R.F. Souza, Acid increases MAPK-mediated proliferation in Barrett's esophageal adenocarcinoma cells via intracellular acidification through a Cl-/HCO3- exchanger. Am J Physiol Gastrointest Liver Physiol. 289, G991-G997 (2005)

36. K. Jaiswal, V. Tello, C. Lopez-Guzman, F. Nwariaku, T. Anthony, G.A. Sarosi Jr., Bile salt exposure causes phosphatidyl-inositol-3kinase-mediated proliferation in a Barrett's adenocarcinoma cell line. Surgery 136, 160-168 (2004)

37. K. Jaiswal, C. Lopez-Guzman, R.F. Souza, S.J. Spechler, G.A. Sarosi Jr., Bile salt exposure increases proliferation through p38 and ERK MAPK pathways in a non-neoplastic Barrett's cell line. Am J Physiol Gastrointest Liver Physiol. 290, G335-G342 (2006)

38. Y. Hao, S. Sood, G. Triadafilopoulos, J.H. Kim, Z. Wang, P. Sahbaie, M.B. Omary, A.W. Lowe, Gene expression changes associated with Barrett's esophagus and Barrett's-associated adenocarcinoma cell lines after acid or bile salt exposure. BMC Gastroenterol. 7, 7-24 (2007)

39. C. Morgan, W. Alazawi, P. Sirieix, T. Freeman, N. Coleman, R. Fitzgerald, In vitro acid exposure has a differential effect on apoptotic and proliferative pathways in a Barrett's adenocarcinoma cell line. Am J Gastroenterol. 99, 218-224 (2004)

40. R.F. Souza, K. Shewmake, S. Pearson, G.A. Sarosi Jr., L.A. Feagins, R.D. Ramirez, L.S. Terada, S.J. Spechler, Acid increases proliferation via ERK and p38 MAPK-mediated increases in cyclooxygenase-2 in Barrett's adenocarcinoma cells. Am J Physiol Gastrointest Liver Physiol. 287, G743-G748 (2004)

41. P.H. Riegman, K.J. Vissers, J.C. Alers, E. Geelen, W.C. Hop, H.W. Tilanus, H. van Dekken, Genomic alterations in malignant transformation of Barrett's esophagus. Cancer Res. 61, 31643170 (2001)

42. E. Rumiato, G. Pasello, M. Montagna, M.C. Scaini, G.L. De Salvo, A. Parenti, M. Cagol, A. Ruol, E. Ancona, A. Amadori, D. Saggioro, DNA copy number profile discriminates between esophageal adenocarcinoma and squamous cell carcinoma and represents an independent prognostic parameter in esophageal adenocarcinoma. Cancer Lett. 310, 84-93 (2011)

43. Y. Takahashi, Y. Amano, T. Yuki, Y. Mishima, Y. Tamagawa, G. Uno, N. Ishimura, S. Sato, S. Ishihara, Y. Kinoshita, Impact of the composition of gastric reflux bile acids on Barrett's oesophagus. Dig Liver Dis. 43, 692-697 (2011)

44. R. Sharma, F. Majer, V.K. Peta, J. Wang, R. Keaveney, D. Kelleher, A. Long, J.F. Gilmer, Bile acid toxicity structure- 
activity relationships: correlations between cell viability and lipophilicity in a panel of new and known bile acids using an oesophageal cell line (HET-1A). Bioorg Med Chem. 18, 68866895 (2010)

45. P.R. Debruyne, E.A. Bruyneel, X. Li, A. Zimber, C. Gespach, M.M. Mareel, The role of bile acids in carcinogenesis. Mutat Res. 480-481, 359-369 (2001)

46. G.J. Jenkins, F.R. D’Souza, S.H. Suzen, Z.S. Eltahir, S.A. James, J.M. Parry, P.A. Griffiths, J.N. Baxter, Deoxycholic acid at neutral and acid $\mathrm{pH}$, is genotoxic to oesophageal cells through the induction of ROS: The potential role of anti-oxidants in Barrett's oesophagus. Carcinogenesis 28, 136-142 (2007)

47. M.M. Abdel-Latif, J. O'Riordan, H.J. Windle, E. Carton, N. Ravi, D. Kelleher, J.V. Reynolds, NF-kappaB activation in esophageal adenocarcinoma: relationship to Barrett's metaplasia, survival, and response to neoadjuvant chemoradiotherapy. Ann Surg. 239, 491-500 (2004)

48. A.J. Jolly, C.P. Wild, L.J. Hardie, Acid and bile salts induce DNA damage in human oesophageal cell lines. Mutagenesis 19, 319324 (2004)

49. T. Liu, X. Zhang, C.K. So, S. Wang, P. Wang, L. Yan, R. Myers, Z. Chen, A.P. Patterson, C.S. Yang, X. Chen, Regulation of $\mathrm{Cdx} 2$ expression by promoter methylation, and effects of $\mathrm{Cdx} 2$ transfection on morphology and gene expression of human esophageal epithelial cells. Carcinogenesis 28, 488-496 (2007)

50. X. Huo, H.Y. Zhang, X.I. Zhang, J.P. Lynch, E.D. Strauch, J.Y. Wang, S.D. Melton, R.M. Genta, D.H. Wang, S.J. Spechler, R.F. Souza, Acid and bile salt-induced CDX2 expression differs in squamous cells from patients with and without Barrett's esophagus. Gastroenterology 139, 194-203 (2010)

51. A.H. van Roon, G.C. Mayne, B.P. Wijnhoven, D.I. Watson, M.P. Leong, G.E. Neijman, M.Z. Michael, A.R. McKay, D. Astill, D.J. Hussey, Impact of gastro-esophageal reflux on mucin mRNA expression in the esophageal mucosa. J Gastrointest Surg. 12, 1331-1340 (2008)

52. X. Huo, S. Juergens, X. Zhang, D. Rezaei, C. Yu, E.D. Strauch, J.Y. Wang, E. Cheng, F. Meyer, D.H. Wang, Q. Zhang, S.J. Spechler, R.F. Souza, Deoxycholic acid causes DNA damage while inducing apoptotic resistance through NF-kappaB activation in benign Barrett's epithelial cells. Am J Physiol Gastrointest Liver Physiol. 301, G278-G286 (2011)

53. G.J. Jenkins, J. Cronin, A. Alhamdani, N. Rawat, F. D'Souza, T. Thomas, Z. Eltahir, A.P. Griffiths, J.N. Baxter, The bile acid deoxycholic acid has a non-linear dose response for DNA damage and possibly NF-kappaB activation in oesophageal cells, with a mechanism of action involving ROS. Mutagenesis 23, 399-405 (2008)

54. A.J. Jolly, C.P. Wild, L.J. Hardie, Sodium deoxycholate causes nitric oxide mediated DNA damage in oesophageal cells. Free Radic Res. 43, 234-240 (2009)

55. T. Soma, J. Kaganoi, A. Kawabe, K. Kondo, S. Tsunoda, M. Imamura, Y. Shimada, Chenodeoxycholic acid stimulates the progression of human esophageal cancer cells: a possible mechanism of angiogenesis in patients with esophageal cancer. Int J Cancer 119, 771-782 (2006)

56. J. Wu, J. Gong, J. Geng, Y. Song, Deoxycholic acid induces the overexpression of intestinal mucin, MUC2, via NF-kB signaling pathway in human esophageal adenocarcinoma cells. BMC Cancer 8, 333 (2008)

57. N. Vaninetti, L. Williams, L. Geldenhuys, G.A. Porter, D.L. Guernsey, A.G. Casson, Regulation of CDX2 expression in esophageal adenocarcinoma. Mol Carcinog. 48, 965-974 (2009)

58. D.J. Morrow, N.E. Avissar, L. Toia, E.M. Redmond, T.J. Watson, C. Jones, D.P. Raymond, V. Litle, J.H. Peters, Pathogenesis of Barrett's esophagus: bile acids inhibit the Notch signaling pathway with induction of CDX2 gene expression in human esophageal cells. Surgery 146, 714-721 (2009)

59. S. Song, S. Guha, K. Liu, N.S. Buttar, R.S. Bresalier, COX-2 induction by unconjugated bile acids involves reactive oxygen species-mediated signalling pathways in Barrett's oesophagus and oesophageal adenocarcinoma. Gut 56, 1512-1521 (2007)

60. S.P. Duggan, W.M. Gallagher, E.J. Fox, M.M. Abdel-Latif, J.V. Reynolds, D. Kelleher, Low $\mathrm{pH}$ induces co-ordinate regulation of gene expression in oesophageal cells. Carcinogenesis 27, 319-327 (2006)

61. H.Y. Zhang, K. Hormi-Carver, X. Zhang, S.J. Spechler, R.F. Souza, In benign Barrett's epithelial cells, acid exposure generates reactive oxygen species that cause DNA double-strand breaks. Cancer Res. 69, 9083-9089 (2009)

62. M.C. Carey, Bile acids and bile salts: ionization and solubility properties. Hepatology 4, 66S-71S (1984)

63. A. Roda, A. Fini, Effect of nuclear hydroxy substituents on aqueous solubility and acidic strength of bile acids. Hepatology 4, 72S-76S (1984)

64. A. Fini, A. Roda, Chemical properties of bile acids. IV. Acidity constants of glycine-conjugated bile acids. J Lipid Res. 28, 755759 (1987)

65. W.K. Kauer, H.J. Stein, Emerging concepts of bile reflux in the constellation of gastroesophageal reflux disease. J Gastrointest Surg 14(Suppl 1), S9-16 (2009)

66. J.W. Harmon, T. Doong, T.R. Gadacz, Bile acids are not equally damaging to the gastric mucosa. Surgery 84, 79-86 (1978)

67. L.A. Feagins, H.Y. Zhang, X. Zhang, K. Hormi-Carver, T. Thomas, L.S. Terada, S.J. Spechler, R.F. Souza, Mechanisms of oxidant production in esophageal squamous cell and Barrett's cell lines. Am J Physiol Gastrointest Liver Physiol. 294, G411-G417 (2008)

68. A. Goldman, H.D. Chen, H.B. Roesly, K.A. Hill, M.E. Tome, B. Dvorak, H. Bernstein, K. Dvorak, Characterization of squamous esophageal cells resistant to bile acids at acidic $\mathrm{pH}$ : implication for Barrett's esophagus pathogenesis. Am J Physiol Gastrointest Liver Physiol. 300, G292-G302 (2011)

69. A. Goldman, A. Condon, E. Adler, M. Minnella, C. Bernstein, H. Bernstein, K. Dvorak, Protective effects of glycoursodeoxycholic acid in Barrett's esophagus cells. Dis Esophagus 23, 83-93 (2010)

70. A.J. Cameron, A.S. Arora, Barrett's esophagus and reflux esophagitis: is there a missing link? Am J Gastroenterol. 97, 273-278 (2002)

71. M. Coenraad, A.A. Masclee, J.W. Straathof, S. Ganesh, G. Griffioen, C.B. Lamers, Is Barrett's esophagus characterized by more pronounced acid reflux than severe esophagitis? Am J Gastroenterol. 93, 1068-1072 (1998)

72. E. Savarino, P. Zentilin, M. Frazzoni, D.L. Cuoco, D. Pohl, P. Dulbecco, E. Marabotto, G. Sammito, L. Gemignani, R. Tutuian, V. Savarino, Characteristics of gastro-esophageal reflux episodes in Barrett's esophagus, erosive esophagitis and healthy volunteers. Neurogastroenterol Motil. 22, 1061-e280 (2010)

73. E. Looby, M.M. Abdel-Latif, V. Athié-Morales, S. Duggan, A. Long, D. Kelleher, Deoxycholate induces COX-2 expression via Erk1/2-, p38-MAPK and AP-1-dependent mechanisms in esophageal cancer cells. BMC Cancer 9, 190 (2009)

74. R.N. Keswani, A. Chumsangsri, R. Mustafi, J. Delgado, E.E. Cohen, M. Bissonnette, Sorafenib inhibits MAPK-mediated proliferation in a Barrett's esophageal adenocarcinoma cell line. Dis Esophagus 21, 514-521 (2008)

75. G. Burnat, T. Rau, E. Elshimi, E.G. Hahn, P.C. Konturek, Bile acids induce overexpression of homeobox gene CDX-2 and vascular endothelial growth factor (VEGF) in human Barrett's esophageal mucosa and adenocarcinoma cell line. Scand J Gastroenterol. 42, 1460-1465 (2007)

76. C. Mariette, G. Piessen, E. Leteurtre, B. Hemon, J.P. Triboulet, I. van Seuningen, Activation of MUC1 mucin expression by bile acids in human esophageal adenocarcinomatous cells and 
tissues is mediated by the phosphatidylinositol 3-kinase. Surgery 143, 58-71 (2008)

77. G.J. Jenkins, K. Harries, S.H. Doak, A. Wilmes, A.P. Griffiths, J.N. Baxter, J.M. Parry, The bile acid deoxycholic acid (DCA) at neutral $\mathrm{pH}$ activates NF-kappaB and induces IL-8 expression in oesophageal cells in vitro. Carcinogenesis 25, 317-323 (2004)

78. A.J. Bredenoord, G.J. Hemmink, A.J. Smout, Relationship between gastro-oesophageal reflux pattern and severity of mucosal damage. Neurogastroenterol Motil. 21, 807-812 (2009)

79. M. Bajpai, J. Liu, X. Geng, R.F. Souza, P.S. Amenta, K.M. Das, Repeated exposure to acid and bile selectively induces colonic phenotype expression in a heterogeneous Barrett's epithelial cell line. Lab Invest. 88, 643-651 (2008)

80. K.M. Das, Y. Kong, M. Bajpai, D. Kulkarni, X. Geng, P. Mishra, D. Banerjee, K. Hirshfield, Transformation of benign Barrett's epithelium by repeated acid and bile exposure over 65 weeks: a novel in vitro model. Int J Cancer 128, 274-282 (2011)

81. J. Majka, K. Rembiasz, M. Migaczewski, A. Budzynski, A. Ptak-Belowska, R. Pabianczyk, K. Urbanczyk, A. Zub-Pokrowiecka, M. Matlok, T. Brzozowski, Cyclooxygenase-2 (COX-2) is the key event in pathophysiology of Barrett's esophagus. Lesson from experimental animal model and human subjects. J Physiol Pharmacol. 61, 409-418 (2010)

82. X. Chen, R. Qin, B. Liu, Y. Ma, Y. Su, C.S. Yang, J.N. Glickman, R.D. Odze, N.J. Shaheen, Multilayered epithelium in a rat model and human Barrett's esophagus: similar expression patterns of transcription factors and differentiation markers. BMC Gastroenterol. 8:1, 1 (2008)

83. E.M. van Soest, J.P. Dieleman, P.D. Siersema, M.C. Sturkenboom, E.J. Kuipers, Increasing incidence of Barrett's oesophagus in the general population. Gut 54, 1062-1066 (2005)
84. T. Bright, A. Schloithe, J.A. Bull, R.J. Fraser, P. Bampton, D.I. Watson, Outcome of endoscopy surveillance for Barrett's oesophagus. ANZ J Surg. 79, 812-816 (2009)

85. N. Fahmy, J.F. King, Barrett's esophagus: an acquired condition with genetic predisposition. Am J Gastroenterol. 88, 1262-1265 (1993)

86. A. Chak, H. Ochs-Balcom, G. Falk, W.M. Grady, M. Kinnard, J.E. Willis, R. Elston, C. Eng, Familiality in Barrett's esophagus, adenocarcinoma of the esophagus, and adenocarcinoma of the gastroesophageal junction. Cancer Epidemiol Biomarkers Prev. 15, 1668-1673 (2006)

87. M. Pera, M.J. Brito, R. Poulsom, E. Riera, L. Grande, A. Hanby, N.A. Wright, Duodenal-content reflux esophagitis induces the development of glandular metaplasia and adenosquamous carcinoma in rats. Carcinogenesis 21, 1587-1591 (2000)

88. H. Kumagai, K. Mukaisho, H. Sugihara, M. Bamba, T. Miyashita, K. Miwa, T. Hattori, Cell kinetic study on histogenesis of Barrett's esophagus using rat reflux model. Scand J Gastroenterol. 38, 687692 (2003)

89. M. Raggi, R. Langer, M. Feith, H. Friess, M. Schauer, J. Theisen, Successful evaluation of a new animal model using mice for esophageal adenocarcinoma. Langenbecks Arch Surg. 395, 347$350(2010)$

90. S.E. Attwood, L.A. Harrison, S.L. Preston, J.A. Jankowski, Esophageal adenocarcinoma in "mice and men": back to basics! Am J Gastroenterol. 103, 2367-2372 (2008)

91. K. Pavlov, C.C. Maley, New models of neoplastic progression in Barrett's oesophagus. Biochem Soc Trans. 38, 331-336 (2010)

92. C.J. Buskens, J.B. Hulscher, T.M. van Gulik, F.J. Ten Kate, J.J. van Lanschot, Histopathologic evaluation of an animal model for Barrett's esophagus and adenocarcinoma of the distal esophagus. J Surg Res. 135, 337-344 (2006) 